\title{
FODDER YIELD, NUTRIENT UPTAKE AND ECONOMICS OF BABY CORN FODDER (ZEA MAYS L.) AS INFLUENCED BY DATE OF SOWING AND ROW SPACING
}

\author{
*Lipika Talukdar, Pradip Chandra Bora, Sontara Kalita and Khagen kurmi
}

Assam Agricultural University, Jorhat -13

*Corresponding author

DOI: https://doi.org/10.51193/IJAER.2021.7114

\section{ABSTRACT}

A field experiment was carried out at the Instructional-Cum-Research farm, Assam Agricultural University, Jorhat in the year of 2017-18 during rabi season. The experiment was laid out in split-plot design and replicated thrice. The treatments consist of two different factors, viz., four dates of sowing $31^{\text {st }}$ October $\left(D_{1}\right), 10^{\text {th }}$ November $\left(D_{2}\right), 20^{\text {th }}$ November $\left(D_{3}\right)$ and $30^{\text {th }}$ November $\left(D_{4}\right)$ and three row spacing $60 \mathrm{~cm}$ x $20 \mathrm{~cm}\left(\mathrm{~S}_{1}\right), 45 \mathrm{~cm}$ x $20 \mathrm{~cm}\left(\mathrm{~S}_{2}\right)$ and $30 \mathrm{~cm}$ x $20 \mathrm{~cm}\left(\mathrm{~S}_{3}\right)$. Experimental findings revealed that crops sown on $31^{\text {st }}$ October recorded the higher green fodder yield by $12.52,14.72$ and 26.68 per cent, respectively and the higher dry fodder yield by 7.5 , 15.84, 26.07 per cent, respectively over $10^{\text {th }}$ November, $20^{\text {th }}$ November and $30^{\text {th }}$ November sowing. Similarly, fodder productivity was the highest on $31^{\text {st }}$ October sowing by $12.52,14.72$ and 26.68 per cent, respectively over $10^{\text {th }}$ November, $20^{\text {th }}$ November and $30^{\text {th }}$ November sowing. Green fodder and dry fodder yield were found to be the higher under spacing $45 \mathrm{~cm} \times 20 \mathrm{~cm}$, $363.34 \mathrm{q} \mathrm{ha}^{-1}$ and $57.2 \mathrm{qha}^{-1}$, respectively among all the spacings. Green fodder yield obtained under $45 \mathrm{~cm}$ x $20 \mathrm{~cm}$ spacing increased by 16.85 and 13.11 per cent and dry fodder yield by 12.59 and 5.53 per cent as compared to $60 \mathrm{~cm} \mathrm{x} 20 \mathrm{~cm}$ and $30 \mathrm{~cm}$ x $20 \mathrm{~cm}$, respectively. Fodder productivity was found to be the higher by 16.84 and 13.11 per cent over the spacing $60 \mathrm{~cm} \mathrm{x} 20$ $\mathrm{cm}$ and $30 \mathrm{~cm}$ x $20 \mathrm{~cm}$, respectively. The total N, P and $\mathrm{K}$ uptake was also higher under $45 \mathrm{~cm} \mathrm{x}$ $20 \mathrm{~cm}$ spacing than rest of the spacing treatments. In terms of economics, higher gross return (Rs. 2,07,011.11 ha-1) and net return (Rs. 1,60,224.11 ha-1) with benefit: cost (3.42) and economic efficiency (1335.20 Rs ha ${ }^{-1} \mathrm{day}^{-1}$ ) were recorded by the $31^{\text {st }}$ October sown crop than other dates of sowing. Among different spacing the highest gross return (Rs. 2,02,627.50 ha-1), net return (Rs. 1,52,486.10 ha ${ }^{-1}$ ), benefit: cost (3.04) and economic efficiency (1270.72 Rs. ha ${ }^{1} \mathrm{day}^{-1}$ ) were recorded under the spacing $45 \mathrm{~cm}$ x $20 \mathrm{~cm}$ than other spacings. 
Keywords: Baby corn, Sowing, Row spacing, Fodder yield, Fodder productivity and Economic efficiency

\section{INTRODUCTION}

The production of quality fodder is very important for keeping the livestock healthy and it plays an important role in dairy industry. Productivity of especially milch animals in India is very low as compared to developed countries due to lack of availability of quality fodder to the animals (Patel et al., 2011). At present, country faces a net deficit of $62.7 \%$ green fodder, $23.5 \%$ crop residues and $64 \%$ feeds resulting crude protein $(28.4 \%)$ and total digestible nutrients (24.1\%) deficiency and trend could well continue in future also (Chotia and Singh, 2005). In India, cropped area under fodder is only $4.2-4.4 \%$ of the total cultivated area and there is hardly any scope of expansion due to increasing pressure on agricultural land for food and cash crop (Mahdi et al., 2012). Solution, therefore, lies in increasing the quality fodder production on limited space and time.

Baby corn (Zea mays L.), being one of the most important dual purpose crops, is grown widely round the year for baby corn as well as green fodder in India. It has an edge over other cultivated fodder crop due to its higher production potential, wider adaptability, fast growing nature, succulent, palatable, excellent fodder quality, free from toxicants and can be safely fed to animals at any stage of crop growth. Baby corn production has been directly integrated with dairying farms in different countries because only $13-20 \%$ of fresh ear weight is used as human food and the rest (silk, husk and green stalk) can be used as excellent feed materials for milch ruminants to improve their productivity. By adopting the good agro-techniques, it could produce 40-45 t/ha of fresh green fodder, which raises net income of 40-45 $\times 103$ Rs./ha as it may prove boon for small and marginal farmers for improving their socio-economic conditions (Kumar et al., 2015).

Therefore, an efficient production technology for baby corn needs to be developed to achieve the higher remunerative yield in terms of corn and green and dry fodder yield of baby corn. The proper sowing time exerts a marked effect on the growth and eventually the yield of crop. When sowing is delayed in winter season due to low temperature, crop growth is less and hence reduce fodder yield along with cob yield.

Again, the space allowed to individual plant is one of the determining factors controlling their development and yield. Closer spacing leads to overcrowding and more plant competition for growth factors, whereas wider spacing reduce the plant population enhance the vegetative growth and provide favourable condition to weed growth and thereby decreasing the total yield. The optimum plant spacing provides better conditions for plant growth which results in timely 
International Journal of Agriculture and Environmental Research

ISSN: 2455-6939

Volume: 07, Issue: 01 "January-February 2021"

commencement of reproductive phase and formation of sink. The establishment of an optimum plant population per unit area of land is the contributory factor, which determines the yield of baby corn.

\section{MATERIALS AND METHODS}

The field experiment was carried out at the Instructional-cum-Research Farm. Assam Agricultural University, Jorhat-13 during the rabi season of 2017-18. The site is situated at $26^{\circ} 47^{\prime} \mathrm{N}$ latitude and $94^{\circ} 12^{\prime} \mathrm{E}$ longitude with an altitude of 86.56 meter above the mean sea level. Jorhat is a sub-tropical place with hot and humid summers and cold and dry winters. The normal monsoon rain starts from the months of June and continues up to September with premonsoon shower from mid March to April. The experiment was laid out in split-plot design and replicated thrice. The treatments consist of four dates of sowing 31stOctober (D1), 10th November (D2), 20th November (D3) and 30th November (D4) and three row spacing $60 \mathrm{~cm} \mathrm{x}$ $20 \mathrm{~cm}$ (S1), $45 \mathrm{~cm} \times 20 \mathrm{~cm}$ (S2) and $30 \mathrm{~cm} \times 20 \mathrm{~cm}$ (S3). The baby corn cv. G-5414 was sown with application of recommended N:P2O:K2O (90:60:60 $\mathrm{kg} \mathrm{ha}^{-1}$ ) and farm yard manure (FYM) @ 2.5t ha ${ }^{-1}$. At the time of last ploughing FYM was applied and mixed thoroughly with soil. Full dose of phosphatic and potassic fertilizers and half dose of nitrogenous fertilizers were applied as uniformly before sowing. The rest half of the nitrogenous fertilizer was applied as top dressing at the time of earthing up (30DAS). Harvesting of baby corn was done at 2-3 days of silking. After the picking of cobs, the green plants were allowed to stand in the field for a week. By this time all the plants were cut close to the ground and the total weight of all plants from each plot was taken. Per plot yields was then converted to $\mathrm{q} \mathrm{ha}^{-1}$. Gross returns, net returns and benefit :cost were worked out on the basis of prevailing market price of inputs and produce. Samples of fodder maize were collected after harvest and oven-dried and further subjected to chemical analysis by following standard procedures. Obtained data were statistically analyzed using F-test. The significant differences between treatment means were compared with critical differences at 5\% level of probability (Gomez and Gomez, 1984).

\section{RESULTS AND DISCUSSION}

\section{Green and dry fodder yield $\left(\mathrm{qha}^{-1}\right)$}

The data present in Table 1 shows that among different dates of sowing the highest green fodder yield of $373.93 \mathrm{q} \mathrm{ha}^{-1}$ and dry fodder yield $58.5 \mathrm{q} \mathrm{ha}{ }^{-1}$ were recorded under $31^{\text {st }}$ October $\left(D_{1}\right)$ sown crop which were significantly higher than those of $20^{\text {th }}$ November $\left(\mathrm{D}_{3}\right)$ and $30^{\text {th }}$ November $\left(\mathrm{D}_{4}\right)$ sown crop. Crop sown on $31^{\text {st }}$ October increased the fodder yield by 11.13, 12.84 and 21.06 per cent over $10^{\text {th }}$ November $\left(\mathrm{D}_{2}\right), 20^{\text {th }}$ November $\left(\mathrm{D}_{3}\right)$ and $30^{\text {th }}$ November $\left(\mathrm{D}_{4}\right)$, respectively. The increased in fodder yield might be due to better vegetative growth of the crop in terms of 
International Journal of Agriculture and Environmental Research

ISSN: 2455-6939

Volume: 07, Issue: 01 "January-February 2021"

more plant height, number of leaves, leaf area index, dry matter accumulation and crop growth rate. Significant reduction in fodder yield due to late sowing than $31^{\text {st }}$ October might be due to delay in sowing of baby corn and reported in different parts of the country by several workers like Porwal and Jain (1999), Kruczek (2010), Bairagi et al. (2015) and Singh et al. (2015).

The data present in Table 1 shows that green fodder and dry fodder yield differed significantly due to different row spacing. The highest green fodder yield $363.34 \mathrm{q} \mathrm{ha}^{-1}$ and dry fodder yield $57.2 \mathrm{q} \mathrm{ha}^{-1}$ were recorded under the spacing of $45 \mathrm{~cm} \times 20 \mathrm{~cm}\left(\mathrm{~S}_{2}\right)$ which were significantly higher than the values of $60 \mathrm{~cm} \times 20 \mathrm{~cm}\left(\mathrm{~S}_{1}\right)$ and $30 \mathrm{~cm} \times 20 \mathrm{~cm}\left(\mathrm{~S}_{3}\right)$. The green fodder yield increased by 16.85 per cent and 13.11 per cent under $S_{2}$ over $S_{1}$ and $S_{3}$, respectively. These results are in conformity with the findings of Ramachandrappa et al. (2004), Thavaprakash et al. (2005), Kar et al. (2006), Thavaprakaash and Velayudham (2009), Arvadiya et al. (2012), Rathika (2014) and Ghosh et al. (2017) who also found that increase in plant population up to 83.3 thousand plants $\mathrm{ha}^{-1}$ increased fodder yield which was reduced thereafter. The green fodder yield obtained under closer row spacing of $30 \mathrm{~cm}$ x $20 \mathrm{~cm}$ was lower as compared to other row spacing. It might be because of interaction of more number of plants for natural resources or growth factors such as light, water, nutrients etc. under $30 \mathrm{~cm} \times 20 \mathrm{~cm}$ spacing resulting less resource use efficiency in the same. The possible reason for increased yield under row spacing $45 \mathrm{~cm}$ x $20 \mathrm{~cm}$ might be due to optimum number of plants per unit area resulting in higher green fodder yield. The lower green fodder yield was noticed under $60 \mathrm{~cm}$ x $20 \mathrm{~cm}$ spacing which was due to lesser number of plants per unit area under this row spacing as compared to rest of the treatments. Similar results regarding the green fodder yield of baby corn were reported by Thakur et al. (1997), Sukanya et al. (1998), and Thakur Sharma (2000) and Sobhana et al. (2012) who also envisaged that green fodder yield increased significantly with decrease in row spacing i.e., with increase in plant population.

\section{Fodder productivity $\left(\mathrm{kg} \mathrm{ha}^{-1} \mathrm{day}^{-1}\right)$}

The data present in Table 1 shows that among different dates of sowing significantly higher fodder productivity of baby corn was recorded under $31^{\text {st }}$ October sowing, and it increased by $12.52,14.72$ and 26.68 per cent over $10^{\text {th }}$ November, $20^{\text {th }}$ November and $30^{\text {th }}$ November sowing, respectively. This indicated that baby corn fodder recovery was delayed with delayed date of sowing.

Similarly, fodder productivity differed significantly due to different row spacing. The highest fodder productivity was recorded under the spacing $45 \mathrm{~cm} \times 20 \mathrm{~cm}\left(\mathrm{~S}_{2}\right)$ which was significantly higher than the values under $60 \mathrm{~cm} \times 20 \mathrm{~cm}\left(\mathrm{~S}_{1}\right)$ and $30 \mathrm{~cm} \times 20 \mathrm{~cm}\left(\mathrm{~S}_{3}\right)$, and it increased by 16.84 and 13.11 per cent over the spacing $60 \mathrm{~cm} \times 20 \mathrm{~cm}\left(\mathrm{~S}_{1}\right)$ and $30 \mathrm{~cm} \times 20 \mathrm{~cm}\left(\mathrm{~S}_{2}\right)$, respectively. 
International Journal of Agriculture and Environmental Research

ISSN: 2455-6939

Volume: 07, Issue: 01 "January-February 2021"

\section{Nutrient content (\%) and uptake $\left(\mathrm{kg} \mathrm{ha}^{-1}\right)$}

The dates of sowing had non-significant effect on the nutrient content of baby corn. However, higher $\mathrm{N}, \mathrm{P}$ and $\mathrm{K}$ content of fodder were found in $31^{\text {st }}$ October $\left(\mathrm{D}_{1}\right)$ as compared to all other sowing treatments. The effect of sowing dates on nitrogen uptake by fodder as well as total uptake was found to be statistically significant. The N-uptake by fodder and total $\mathrm{N}$ - uptake were higher in $\mathrm{D}_{1}$ sown crop which was comparable to $10^{\text {th }}$ November $\left(\mathrm{D}_{2}\right)$ sown crop. It might be because of the development of root system and leaf canopy were probably affected adversely under late sown condition and consequently, the crop was not able to absorbed or utilized nutrients optimally as compared to early sown crop. These results are in close conformity with Patel et al. (1999) who observed N, P and K content and uptake by fodder have negative association with delay in sowing due to decrease in temperature during the crop growth period. There was non-significant effect of date of sowing on uptake of $\mathrm{P}$ and $\mathrm{K}$ by fodder and total uptake of these two nutrients (Table 2).

The row spacing had non-significant effect on the nutrient content of baby corn fodder. Regarding N, P and K uptake by fodder, the spacing of $45 \mathrm{~cm}$ x $20 \mathrm{~cm}$ recorded significantly higher uptake followed by $60 \mathrm{~cm} \times 20 \mathrm{~cm}$. Higher N, P and $\mathrm{K}$ content by fodder under the wider row spacing of $45 \mathrm{~cm} \times 20 \mathrm{~cm}$ might be due to better vegetative growth of the plants. Availability of sunlight, water and space favor the growth of plant. These results are in closed conformity with Kar et al. (2006), Kunjir et al. (2007), Thavaprakaash and Velayudham (2007), Sobhana et al. (2012) and Kumar et al. (2015).

\section{Economics evaluation}

Economics is the foremost consideration of the farmer's point of view while taking a decision to adopt a new technology. The data in Table 1.indicated that the highest net return of (Rs. $160224.11 \mathrm{ha}^{-1}$ ) was achieved under $31^{\text {st }}$ October sowing, followed by (Rs. $144291.89 \mathrm{ha}^{-1}$ ) with $10^{\text {th }}$ November sowing. Both these treatments also recorded the higher benefit: cost (3.42 and 3.08), economic efficiency (Rs.1335.20 Rs ha ${ }^{-1}$ day $^{-1}$ and Rs.1202.43 Rs ha ${ }^{-1}$ day $^{-1}$ ), respectively. This could be attributed to higher total yield recorded under early sown crop without any additional expenditure. These findings are substantiated with those reported by Patel et al. (1994) at Godhra (Gujarat) and Porwal and Jain (1999) at Banswara (Rajasthan).

As the highest yield was found in the row spacing $45 \mathrm{~cm} \times 20 \mathrm{~cm}$ it also resulted in enhanced net return (Rs. 1,52,486.10 ha ${ }^{-1}$ ), benefit: cost (3.04) and economic efficiency (1270.72 Rs ha -1day ${ }^{-}$ 1) followed by $60 \mathrm{~cm} \times 20 \mathrm{~cm}$ and $30 \mathrm{~cm} \times 20 \mathrm{~cm}$ spacing. The spacing $30 \mathrm{~cm} \times 20 \mathrm{~cm}$ recorded the lowest gross return, net return and benefit:cost among all the row spacing treatments. Similar results were reported by Lala et al. (2013) and Singh et al. (2015). 
Table 1: Fodder yield and economics of baby corn as influenced by date of sowing and row spacing

\begin{tabular}{|c|c|c|c|c|c|c|}
\hline Treatment & $\begin{array}{l}\text { Green fodder } \\
\text { yield }\left(\text { qha }^{-1}\right)\end{array}$ & $\begin{array}{l}\text { Dry fodder } \\
\text { yield }\left(\text { qha }^{-1}\right)\end{array}$ & $\begin{array}{c}\text { Fodder } \\
\text { productivity } \\
\left(\text { kgha }^{-1} \text { day }^{-1}\right)\end{array}$ & Net returns $\left(\operatorname{Rs~ha}^{-1}\right)^{*}$ & $\begin{array}{c}\text { Benefit:c } \\
\text { ost }\end{array}$ & $\begin{array}{c}\text { Economic } \\
\text { efficiency (Rs ha } \\
\left.{ }^{1} \text { day }^{-1}\right)\end{array}$ \\
\hline \multicolumn{7}{|l|}{ Date of sowing } \\
\hline $\mathrm{D}_{1}\left(31^{\text {st }}\right.$ October $)$ & 373.93 & 58.50 & 311.61 & 160224.11 & 3.42 & 1335.20 \\
\hline $\begin{array}{c}\mathrm{D}_{2}\left(10^{\text {th }}\right. \\
\text { November })\end{array}$ & 332.30 & 54.40 & 276.92 & 144291.89 & 3.08 & 1202.43 \\
\hline $\begin{array}{c}\mathrm{D}_{3}\left(20^{\text {th }}\right. \\
\text { November })\end{array}$ & 325.93 & 50.50 & 271.61 & 122588.55 & 2.62 & 1021.57 \\
\hline $\begin{array}{c}\mathrm{D}_{4}\left(30^{\text {th }}\right. \\
\text { November })\end{array}$ & 295.17 & 46.40 & 245.97 & 119511.89 & 2.55 & 995.93 \\
\hline S.Em. $( \pm)$ & 8.17 & 1.20 & 6.34 & - & - & - \\
\hline C.D (0.05) & 28.26 & 3.70 & 20.32 & - & - & - \\
\hline \multicolumn{7}{|l|}{ Spacing $(\mathrm{cm})$} \\
\hline$S_{1}(60 \times 20)$ & 310.94 & 50.80 & 259.12 & 132053.84 & 2.82 & 1100.45 \\
\hline $\mathrm{S}_{2}(45 \times 20)$ & 363.34 & 57.20 & 302.78 & 152486.10 & 3.04 & 1270.72 \\
\hline $\mathrm{S}_{3}(30 \times 20)$ & 321.22 & 54.20 & 267.68 & 107181.34 & 1.88 & 893.18 \\
\hline S.Em. $( \pm)$ & 7.07 & 1.00 & 5.88 & - & - & - \\
\hline C.D (0.05) & 21.20 & 2.80 & 18.31 & - & - & - \\
\hline \multicolumn{7}{|c|}{ Interaction $(\mathrm{D} \times \mathrm{S})$} \\
\hline S.Em. $( \pm)$ & 14.15 & 3.80 & 0.28 & - & - & - \\
\hline C.D (0.05) & NS & NS & NS & - & - & - \\
\hline
\end{tabular}

$* \mathrm{NS}=$ Non - significant

*Net returns include both cob and fodder yield income 
Table 2: Nutrient content and uptake by baby corn fodder as influenced by date of sowing and row spacing

\begin{tabular}{|c|c|c|c|c|c|c|c|c|c|}
\hline \multirow[t]{2}{*}{ Treatments } & \multicolumn{3}{|c|}{ Nitrogen } & \multicolumn{3}{|c|}{ Phosphorus } & \multicolumn{3}{|c|}{ Potassium } \\
\hline & Content & Uptake & $\begin{array}{c}\text { Total } \\
\text { uptake by } \\
\text { plant }^{*}\end{array}$ & Content & Uptake & $\begin{array}{c}\text { Total } \\
\text { uptake by } \\
\text { plant }\end{array}$ & Content & Uptake & $\begin{array}{c}\text { Total } \\
\text { uptake by } \\
\text { plant }\end{array}$ \\
\hline \multicolumn{10}{|c|}{ Dates of sowing } \\
\hline $\begin{array}{l}\mathrm{D}_{1}\left(31^{\mathrm{st}}\right. \\
\text { October })\end{array}$ & 0.62 & 85.20 & 91.53 & 0.16 & 23.58 & 25.13 & 0.88 & 98.00 & 100.94 \\
\hline $\begin{array}{l}\mathrm{D}_{2}\left(10^{\text {th }}\right. \\
\text { November })\end{array}$ & 0.60 & 75.87 & 81.62 & 0.15 & 20.82 & 22.24 & 0.86 & 95.42 & 97.20 \\
\hline $\begin{array}{l}\mathrm{D}_{3}\left(20^{\text {th }}\right. \\
\text { November })\end{array}$ & 0.57 & 69.09 & 73.88 & 0.14 & 19.96 & 20.53 & 0.83 & 95.21 & 96.74 \\
\hline $\begin{array}{l}\mathrm{D}_{4}\left(30^{\text {th }}\right. \\
\text { November })\end{array}$ & 0.55 & 59.96 & 64.43 & 0.14 & 18.58 & 19.66 & 0.82 & 94.22 & 95.64 \\
\hline S.Em. $( \pm)$ & 0.02 & 3.06 & 2.96 & 0.01 & 1.08 & 1.08 & 0.02 & 2.21 & 2.19 \\
\hline C.D (0.05) & $\mathrm{NS}$ & 10.58 & 10.25 & $\mathrm{NS}$ & $\mathrm{NS}$ & $\mathrm{NS}$ & $\mathrm{NS}$ & $\mathrm{NS}$ & $\mathrm{NS}$ \\
\hline \multicolumn{10}{|c|}{ Spacing (cm) } \\
\hline $\mathrm{S}_{1}(60 \times 20)$ & 0.58 & 68.17 & 73.44 & 0.15 & 20.12 & 21.42 & 0.85 & 95.22 & 96.96 \\
\hline $\mathrm{S}_{2}(45 \times 20)$ & 0.61 & 83.11 & 89.20 & 0.16 & 24.35 & 25.87 & 0.86 & 104.92 & 106.76 \\
\hline $\mathrm{S}_{3}(30 \times 20)$ & 0.56 & 66.31 & 70.95 & 0.14 & 17.29 & 18.38 & 0.84 & 87.74 & 89.18 \\
\hline S.Em. $( \pm)$ & 0.01 & 2.65 & 2.57 & 0.01 & 0.94 & 0.94 & 0.02 & 1.92 & 1.90 \\
\hline C.D (0.05) & $\mathrm{NS}$ & 7.94 & 7.69 & $\mathrm{NS}$ & 2.81 & 2.81 & $\mathrm{NS}$ & 5.75 & 5.70 \\
\hline \multicolumn{10}{|c|}{ Interaction (D x S) } \\
\hline S.Em. $( \pm)$ & 0.03 & 5.30 & 5.13 & 0.01 & 1.87 & 1.74 & 0.02 & 1.92 & 1.90 \\
\hline C.D (0.05) & $\mathrm{NS}^{*}$ & $\mathrm{NS}$ & $\mathrm{NS}$ & $\mathrm{NS}$ & $\mathrm{NS}$ & $\mathrm{NS}$ & $\mathrm{NS}$ & $\mathrm{NS}$ & $\mathrm{NS}$ \\
\hline
\end{tabular}

$* \mathrm{NS}=$ Non- significant

*Total uptake by plant include uptake by cob and fodder 
International Journal of Agriculture and Environmental Research

ISSN: 2455-6939

Volume: 07, Issue: 01 "January-February 2021"

\section{REFERENCES}

Arvadiya, L.K.; Raj, V.C.; Patel, T.U and Arvadiya, M.K. (2012). Influence of plant population and weed management on weed flora and productivity of sweet corn. Indian J. Agron. 57(2): 162-167.

Bairagi, S.; Pandit, M. K.; Sidhya, P.; Adhikary, S. and Koundinya, A. V. V. (2015). Impacts of date of planting and crop geometry on growth and yield of baby corn (Zea mays var. rugosa). Journal Crop and Weed. 127-131.

Chotiya, A. and Singh, P. (2005). Effect of graded levels of nitrogen and phosphorus on sorghum fodder production. Forage Res. $31: 218-19$

Ghosh, M.; Maity, S.K.; Gupta, S.K. and Chowdhury, A.R. (2017). Performance of baby corn under different plant densities and fertility levels in lateritic soils of Eastern India. Intern. J. Pure App. Biosci. 5(3): 696-702.

Gomez, K. A. and Gomez, A. A. (1984). Statistical Procedure for Agricultural Research, 2nd edn. John Wiley \& Sons, New York. pp. 241- 71.

Kar, P. P.; Barik, K. C.; Mahapatra, P. K.; Rath, L. M.; Bastia, D. K. and Khanda, C. M. (2006). Effect of planting geometry and nitrogen on yield, economics and nitrogen uptake of sweet corn (Zea mays). Indian J. Agron. 51(1): 43-45.

Kumar, R.; Bohra, J.S. and Singh,A.K.(2015).Fodder yield, nutrient uptake and quality of baby corn (Zea mays L.) as influenced by NPKS and Zn fertilization. Res.on crops. 16(2): 243249.

Kumar, R.M.; Hiremath, S. M. and Nadagouda, B.T. (2015). Effect of single-cross hybrids, plant population and fertility levels on productivity and economics of maize (Zea mays). Indian J. Agron. 60(3): 431-435.

Kunjir, S. S.; Chavan, S. A.; Bhagat, S. B. and Zende, N. B. (2007). Effect of planting geometry, nitrogen levels and micronutrients on the growth and yield of sweet corn. Crop Prot. 2(3): 25-27.

Kruczek, A. (2010). Influence of the sugar maize sowing date and methods of fertilizing with nitrogen and phosphorus on selected agrophages. Progress in Plant Prot. 51(3): 13141318. 
International Journal of Agriculture and Environmental Research

ISSN: 2455-6939

Volume: 07, Issue: 01 "January-February 2021"

Lala, K.; Singh, M.P. and Bhatnagar, A. (2013). Response of planting geometry and nitrogen on quality production of baby corn (Zea mays L.). New Agriculturist 24: 141-146.

Mahdi, S. S.; Hasan, B.; Singh, L. and Ganie, A. M. (2012). Quality of fodder maize (Zea mays L.) and soil health influenced by nitrogen, seed rate and zinc in Kashmir Valley. Indian J. Soil Conserv. $40: 147-51$.

Patel, G.J.; Patel, G.N. and Arha, M.D. (1994). Effect of sowing dates on different varieties of rabi maize. GAU, Res. J. 20(1): 134-136.

Patel, T. U.; Arvadia, M. K.; Malik, P. K.; Patel, D. D. and Patel, P. S. (2011). Production of 248 Kumar, Bohra, Kumawat and Singh oats (Avena sativa) under different cutting managements and split application of nitrogen. Indian J. Agron. 56 : 164-67.

Porwal, M.K. and Jain, H.K. (1999). Effect of sowing dates on winter maize (Zea mays) varieties in command area of southern Rajasthan. Indian J. Agron. 44(3): 560-563.

Rathika, S. (2014). Influence of crop geometry, intercropping and topping practices on green cob yield and fodder quality of baby corn (Zea mays L.). Intern. J. Agil. Sci. 10(1): 182-185.

Ramachandrappa, B.K.; Nanjappa, H.V. and Shivakumar, H.K. (2004). Yield and quality of baby corn (Zea mays L.). as influenced by spacing and fertilizer levels. Acta- AgronomicaHungarica. 52(3): 237-243.

Singh, G.; Kumar, S.; Singh, R. and Singh, S.S. (2015). Growth and yield of baby corn (Zea mays L.) as influenced by varieties, spacings and dates of sowing. Indian J. Agric. 49 (4): 353-357.

Sobhana, V.; Kumar, A.; Idnani, L. K.; Singh, I. and Shivadhar. (2012). Plant population and requirement for baby corn hybrids (Zea mays). Indian Agron. 57(3): 294-296.

Sukanya, T. S.; Nanjappa, H. V. and Ramachandrappa, B. K. (1998). Growth parameters and yield of babycorn as influenced by varieties and spacing. Mysore J. Agric. Sci. 32(4): 264-268.

Thakur, D. R.; Prakash, O.; Kharwara, P. C. and Bhalla, S. K. (1997). Effect of nitrogen and plant spacing on growth, development and yield of baby corn. Indian J. Agron. 42(3): 479-483. 
Thakur, D.R. and Sharma, V. (2000). Effect of planting geometry on baby corn yield in hybrid and composite cultivars of maize (Zea mays). Indian J. Agric. Sci. 70(4): 246-247.

Thavaprakaash, N. and Velayudham, K. (2007). Effect of crop geometry, intercropping systems and INM practices on cob yield and nutrient uptake of baby corn. Asian. J. Agric. Res. 1(1): $10-16$.

Thavaprakaash, N. and Velayudham, K. (2009). Influence of crop geometry, intercropping systems and INM practices on productivity of baby corn (Zea mays L.) based intercropping system. Mysore J. Agric. Sci. 43(4): 686-695.

Thavaprakaash, N.; Velayudham, K. and Muthukumar, V.B. (2005). Effect of crop geometry, intercropping systems and integrated nutrient management practices on productivity of baby corn (Zea mays L.) based intercropping systems. Res. J. Agric. Biol. Sci. 1(4): 295302. 